\title{
Jumping Water Method on Microhydro Power Plant for Water Channel
}

\author{
Syafriyudin, Beny Firman, Prabudtya Bisma W \\ Department of Electrical Engineering, Institut Sains dan Teknologi AKPRIND \\ Yogyakarta, Indonesia \\ dien@akprind.ac.id
}

\begin{abstract}
The most used renewable energy in Indonesia comes from hydro energy. The hydro energy available in Indonesia is around 75,000-76,000 MW. Of the total available water energy in Indonesia, there is only about $3.783 \mathrm{MW}$ to power for large-scale power plants and about $220 \mathrm{MW}$ for small-scale power plants. One small-scale hydro energy source is a small river that has a water speed range of $0.01 \mathrm{M} / \mathrm{s}$ to $2.8 \mathrm{~m} / \mathrm{s}$. Although it only has a low water velocity, the energy stored in it has the potential power to generate electricity. There are three types of waterwheels based on the water flow system, namely: overshot, breast-shot, and under-shot. In the overshot mill, the water through the windmill and the mill are under the flow of water. Water twisted the mill and water fell to the lower surface. The mill moves clockwise. In the breast-shoot wheel, the mill is placed parallel to the flow of water so that water flows through the center of the mill. Water turns the mill counterclockwise. In the undershot mill, the position of the waterwheel is placed slightly upward and slightly touches the water. The flow of water that touches the windmill moves the mill so that it is anticlockwise. And in this final project the author made a new system called Jumping Water, this system works almost the same as the breast-shoot only the wheel is not in a lower condition of the water surface, the bottom position of waterwheel parallel to the bottom of the water channel, which distinguishes the jumping water position Can be altered altitude according to the flow of the water which will affect the speed of the spin mill.
\end{abstract}

Keywords - renewable energy, small-scale power plants, low water velocity, jumping water

\section{INTRODUCTION}

The waterwheel is a renewable and sustainable energy generator with an effective technology system, low-cost operation and maintenance are perfect in rural areas with an environmental water landscape. The traditional wheelchairs and water wheels of the factory, built with simple designs with very basic technology, have a huge economic impact on the rural economy. Traditional water wheels in a water mill built of wood, bamboo and steel recycling components serve as a new green technology that promises no negative effects on the environment. Design with calculations, challenges, and applications along with the future horizontal sphere of axis type of waterwheel. [2]

Micro-hydro is just a term. Micro means small while hydro means water. In practice, this term is not a standard thing but Micro-hydro must use water as its energy source. Power Plant
Micro-hydropower is a term used for power plant installations that use water energy. Water conditions that can be utilized as electricity generating resources are those that have a certain flow capacity and altitude and installation. Small power plants that can use hydropower by utilizing the height of the head (in meters) and the amount of water discharge ( $\mathrm{m} / \mathrm{sec})$. The greater the flow capacity and the height of the installation the greater the energy that can be utilized to generate electrical energy. PLTMH is generally a runoff river type of power plant where the head is obtained not by constructing large dams, but by diverting the flow of river water to one side of the river and then streaming it back to the river at a place where the required height difference has been obtained. The hydroelectric power plant under $200 \mathrm{~kW}$ is classified as PLTMH. [4].

For pedagogical purposes, we may model the wheel physics by using the basic concepts (force, torque, energy, energy) of mechanics and fluid dynamics. With a simple clamp model. The undershot wheels developed here can account well enough for the measurement of efficiency, the undershot model explains why poncelet modification significantly improves efficiency. Secondly, the model highlights the important parameters in the design of the water wheel, it is not difficult to get the undershot ratio to cross its output power limit. Here there are a number of assumptions that the undershot wheel can be optimal and the overshot wheel has $\mathrm{X} 1(\omega \mathrm{r})=1$ for low friction values and for these realistic parameters it indicates that the overshot water wheel is significantly better especially for low water rates with wheel finger The big one [3]

Micro-hydropower plants use water energy to convert to kinetic energy generated from a spinning millwheel. The use of jumping water in the micro-hydro system is very influential on the output power generated by the plant. One of the problems that arise in the use of micro-hydro is that the energy generated changes depending on the season and the environment. This will be greatly felt in areas where extreme drought causes water sources that should be used to drive windmills not working. Therefore it takes a system to regulate the flow of water and water discharge so that rotation of the spin mill can be maximized. From the above problem, the author tries to make the Prototype PLTMh in accordance with the original by additional system jumping water where 
jumping water will be given auto or manual system to raise or lower the height of the angle jumping water to adjust the intensity of water flow, the method used is to conduct measurement experiments of the prototype that has been made.

\section{Micro hydro Power Plant}

Water Wheel

Because the overshot efficiency remains high for various streams, it is suitable in places where water sources vary. However, when the speed and rotation velocity exceeds a certain value, the volumetric loss determines the waste of water, resulting in a decrease in efficiency and possible damage to the wheel. Each cell should only be charged up to $30-50 \%$ of its volume, to reduce volumetric loss during rotation. The tube should be shaped so that the water jet can enter each cell at a natural falling angle, with the gap of each cell slightly wider than the jet, to allow air release. However, in the overshot wheels being studied, it is the potential energy of water that is the main torque for the wheel. The shape of the cell must retain water in the cell to the lowest position, when it eventually empties quickly. Wheel diameter is determined by high difference, while relative speed is not a simple parameter to be optimized. When the wheel spins at a very low speed. When the cell moves too fast, only a small amount of water can enter each cell, due to volumetric loss. From the experimental results, we can claim that for the steering wheel tangent speed is lower than $75-80 \%$ water velocity, high efficiency and fairly constant with wheel speed, In our case study, two different rotation speeds are u Identified: runaway speed $\omega r$, In which the output power tends to be zero $(\omega=4.2$ $\div 4.3 \mathrm{rad} / \mathrm{s}$ ) and critical velocity $\omega \mathrm{cr}$, where the output power begins to decrease bruquely $(\omega \mathrm{cr}=2.7 \mathrm{Rad} / \mathrm{s})$. For higher efficiency than at $80 \%$ for various streams [5]

One of the new renewable energy types is small scale hydro power or often called microhydro or PLTMh. Microhydro obtains energy from a water stream having a certain high difference and water flow velocity, the energy generated by the physical model of waterwheel is a renewable energy can be measured using a digital torque tester that is connected to the axis of the model of the mill. High speed of rotation not necessarily have great energy because if given a little load will greatly affect the speed of rotation of the purpose of this research is to develop technology, materials, mechanical components, electronic components and design of energy resources system, so have a strategic impact to Technological developments and applicable in society, the measurement of a waterwheel rotation using a tachometer yields a permenite spin value (RPM) that affects the energy value generated from the wheel. The model of the mill used is undershot. From the result of research, it is known that the highest speed of roundwheel in H1h1 $(1 \mathrm{~cm}$ high base of the windmill on the bottom of the channel and $1 \mathrm{~cm}$ of water gate downstream) is 13,76 RPM, the highest energy obtained by using torque meter at $\mathrm{H} 1 \mathrm{~h} 1$ is $78,30 \mathrm{cNm}$ or 0.0002175 watthour [7].
In particular, breast-shot waterwheels are used in locations with high flow rates, such as irrigation canals and grinding, with a height generally less than $4 \mathrm{~m}$. In this paper, experimental results are reported to illustrate how rainwater rotation efficiency under different hydraulic and geometric configurations. Two different flow configurations are investigated: the first has a water gate on the upstream of the wheel (the opening is adjustable), the second is a dam. Two dams of different heights were installed on the upstream of the wheel and investigated. The maximum efficiency for opening of flood gates $>0.075 \mathrm{~m}$ is fairly constant in the range between $0.05<\mathrm{Q}<0.08 \mathrm{~m} 3 / \mathrm{s}$ for $\alpha>0.10 \mathrm{~m}$, while efficiency with the dam increases, indicating that the wheel is able to exploit larger volumes The dam water improves the efficiency of the wheels at very low discharge $(\mathrm{Q}<0.03 \mathrm{~m} 3 / \mathrm{s})$, and gives a significant effect on high power inputs $\left(P_{g y}>400 w\right)$. normalized tangential normal speeds are included in the range for cases with gate gates and weirs, respectively. The optimal fill rate is usually included in the range of $0.3 \div 0.5$. This range can be regarded as the optimal operating conditions for a breath shot similar wheel. Therefore, both the correct design of the elevation of the dam and the opening of the sluice can be considered as an appropriate method to optimize working conditions and efficiency of the breath shot wheel. [6]

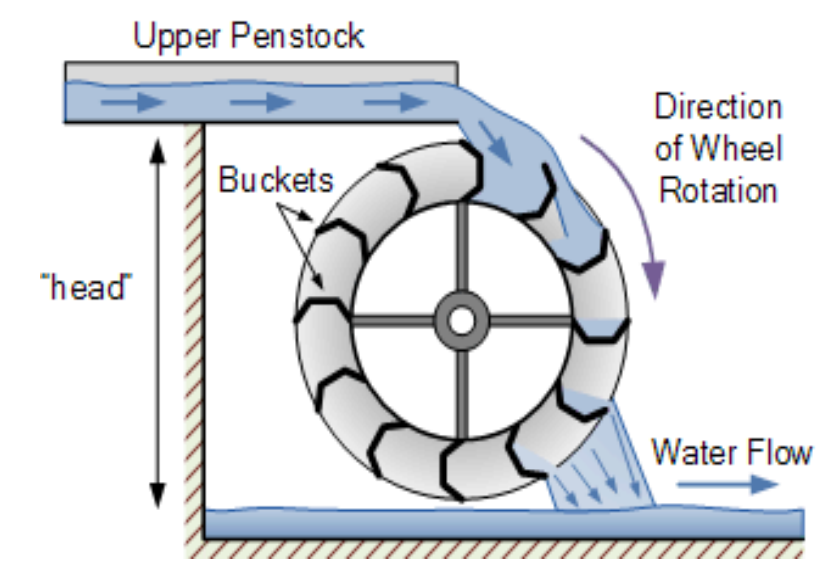

Fig. 1. Overshot waterwheel type

\section{Overshot system}

An overshot waterwheel works when the flowing water falls into the upper part of the blade and due to the gravity of the water wheel rotates. The overshot water mill is the most widely used water mill compared to other types of waterwheels

Advantages

- High efficiency level can reach $85 \%$.

- Does not require heavy flow.

- Simple construction.

- Easy to maintain.

- Simple technology is easy to implement in isolated areas.

Loss

- Since the water flow comes from above it is usually a reservoir of water or a water dam, requiring more investment. 
- Not applicable for high rotary machines.

- Requires more space for placement.

- The power generated is relatively small

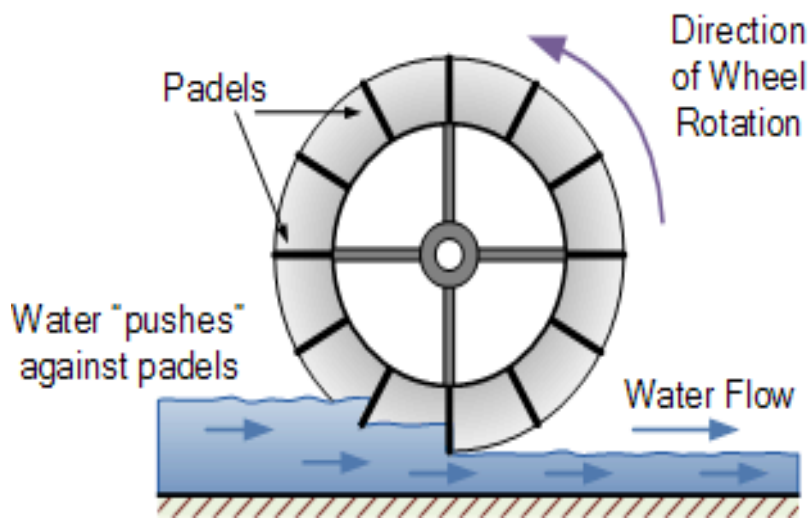

Fig. 2. Undershot waterwheel type

\section{Undershot system}

Undershot water mill works when running water strikes the wall at the bottom of the waterwheel. Undershot water mill rely solely on the water capacity $(\mathrm{Q})$ without having additional advantages of head or different water levels. This type of waterwheel is suitable for installation in shallow, flat waters. This type of waterwheel is also called the "Vitruvian". Where the water flow is opposite to the direction of the blade that turns the mill.

Advantages of Undershot type

- The construction is simpler

- More economical

- Easy to move

Loss

- Small efficiency

- The resulting power is relatively small

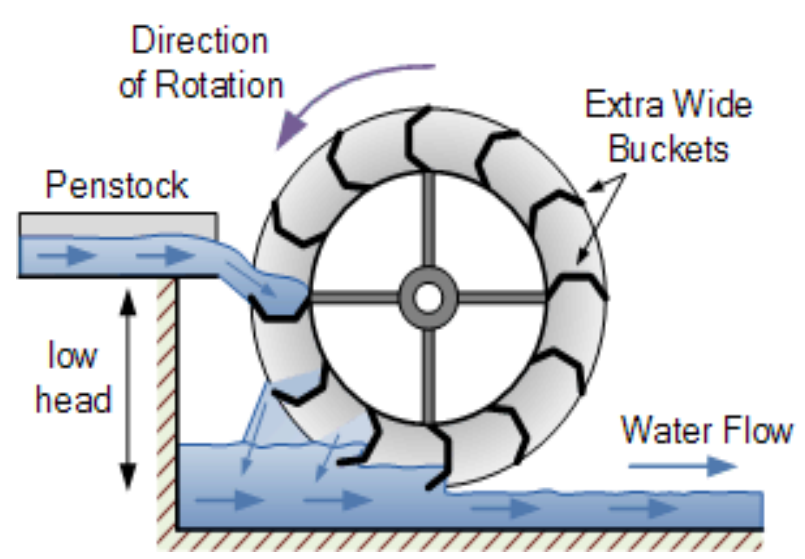

Fig. 3. Breathshot waterwheel type

\section{Breastshot system}

Breastshot water wheel is a blend of overshot and undershot types seen from the energy it receives. The fall distance does not exceed the diameter of the mill, the direction of the water flow that drives the waterwheel around the shaft axis of the waterwheel. This type of water mill improves the performance of an under shot water mill [1].

Advantages

- This type is more efficient than under shot type

- Compared to the overshot type the height of the fall is shorter

- Applicable to flat-flow water sources.

Loss

- The angles of this type are not flat like undershot type (more complicated)

- Required dams on the flow of flat flows

- Efficiency is smaller than the overshot type

The microhydro prototype is designed using a waterwheel with a triangle blade type model to facilitate the wheel in accepting the flow of water from jumping water. As in FIG. 2, there are 3 pieces which are made to form an arch so that water is not immediately wasted but can be accommodated temporarily on the outermost piece of the pin blade which functions in order to increase the resulting torque value.

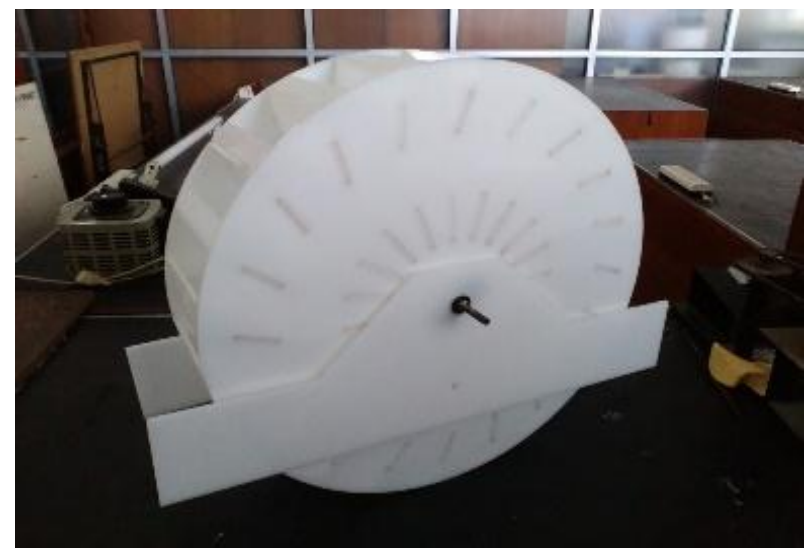

Fig. 4. Waterwheel

\section{DISCUSSION}

\section{Jumping Water}

This microhydro prototype jumping water is very influential on the rotation of the mill, to know the acceleration of rotation speed of the mill, the writer takes into account the angle of jumping water height, by slipping the acrylic slab

In a drawer already mounted on a drain. The test is done in different angles as in figure (3). [8] 


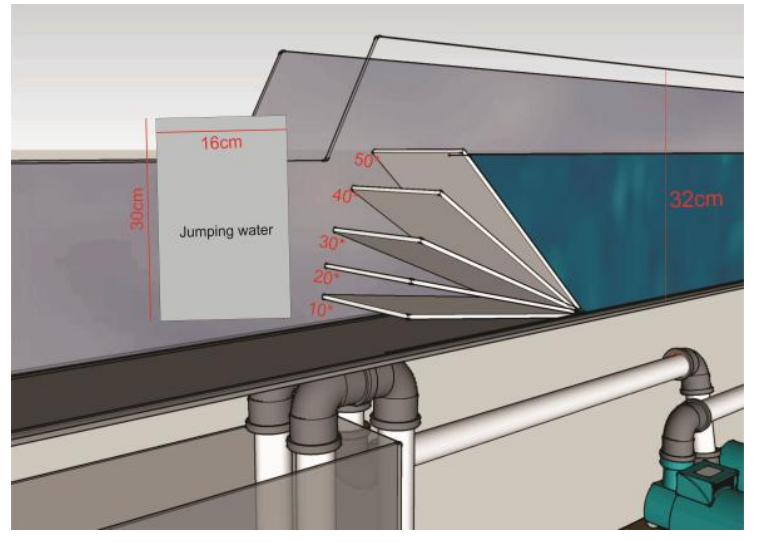

Fig. 5. Jumping water model

Planning system on making micro-hydro prototype with jumping water one of the measurement of angle generated jumping water

The first step is to know the calculation of the angle that will result in the height of Jumping water. [8]

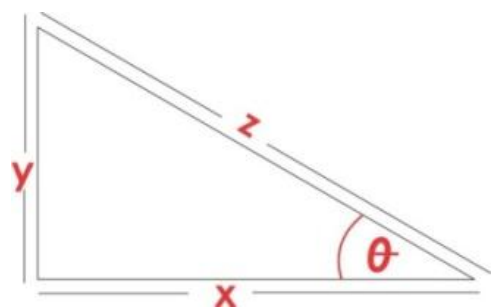

Fig. 6. Right triangle

In figure (4) can be ascertained $\mathrm{Y}$ at altitude, $\mathrm{Z}$ at the slope, and $\mathrm{X}$ at $\mathrm{P} 1$ or the length of the angle calculation. The formula for finding the height of jumping water and $\mathrm{X}$ on $\mathrm{P} 1$ or the length of the angle calculation;

To search long

$\mathrm{X}=\mathrm{Z} \operatorname{Cos} \theta$

$\mathrm{X}(\mathrm{P} 1)=30 \cos 10^{\circ}$

$=29.5 \mathrm{~cm}$

To search high

$\mathrm{Y}=\mathrm{Z} \operatorname{Sin} \theta$

$\mathrm{Y}=30 \operatorname{Sin} 10^{\circ}$

$=5.2 \mathrm{~cm}$

From the results of the calculation of the above angles can be generated as recorded in the table below, the authors conducted trials using 5 experiments, ranging from $10 \mathrm{o}$ to $50^{\circ}$. [8]

TABEL 1. CALCULATION RESULT FOR JUMPING WATER

\begin{tabular}{|c|c|c|c|}
\hline No & angle & $\mathbf{X}(\mathbf{P 1})$ & Y ( high) \\
\hline 1 & $10^{\circ}$ & 29,5 & $5,2 \mathrm{~cm}$ \\
\hline 2 & $20^{\circ}$ & 28,2 & $10,3 \mathrm{~cm}$ \\
\hline 3 & $30^{\circ}$ & 26 & $15 \mathrm{~cm}$ \\
\hline 4 & $40^{\circ}$ & 23 & $19,3 \mathrm{~cm}$ \\
\hline 5 & $50^{\circ}$ & 19,3 & $23 \mathrm{~cm}$ \\
\hline
\end{tabular}

We can see the results of the calculations produced with 5 angle experiments from 10 o to 500 , for $X(\mathrm{P} 1)$ to know the position between the windmill with Jumping water, and for (y) to find the magnitude of the angle Jumping water

\section{RESULTS}

Measurement results on the design of jumping water on microhydro prototype will also be made several measurements, among others;

Measurement of the length and angle of Water Fall

In this measurement when the data is taken and the test of this device the position of the kinci is removed or not using the mill, the water still runs through Jumping Water. This measurement uses beerapa tools such as ruler and bow degree and obtained the results of data as in the table below.

After the results obtained from the data retrieval 5 times the experiment every angle it can be searched average water fall angle and high fall water.

TABEL 1. AVERAGE NUMBER OF DISTANCE MEASUREMENTS AND FALLING ANGLE OF WATER

\begin{tabular}{|l|l|l|l|l|}
\hline Angle & $\begin{array}{c}\text { High } \\
\text { Jumping } \\
\text { water } \\
\text { (cm) }\end{array}$ & $\begin{array}{c}\text { Falling } \\
\text { distance of } \\
\text { water }\end{array}$ & $\begin{array}{c}\text { The falling } \\
\text { angle of the } \\
\text { water }\end{array}$ & RPM \\
\hline $10^{\circ}$ & $5.2 \mathrm{~cm}$ & $8.2 \mathrm{~cm}$ & $35.4^{\mathbf{0}}$ & 6.9 \\
\hline $20^{\circ}$ & $10.3 \mathrm{~cm}$ & $8.82 \mathrm{~cm}$ & $48.8^{\mathbf{0}}$ & 20.43 \\
\hline $30^{\circ}$ & $15 \mathrm{~cm}$ & $8.4 \mathrm{~cm}$ & $53.4^{\mathbf{0}}$ & 26,93 \\
\hline $40^{\circ}$ & $19.3 \mathrm{~cm}$ & $8.92 \mathrm{~cm}$ & $48.2^{\mathbf{0}}$ & 28.16 \\
\hline $50^{\circ}$ & $23 \mathrm{~cm}$ & $10.32 \mathrm{~cm}$ & $51.2^{\mathbf{0}}$ & 30.86 \\
\hline
\end{tabular}

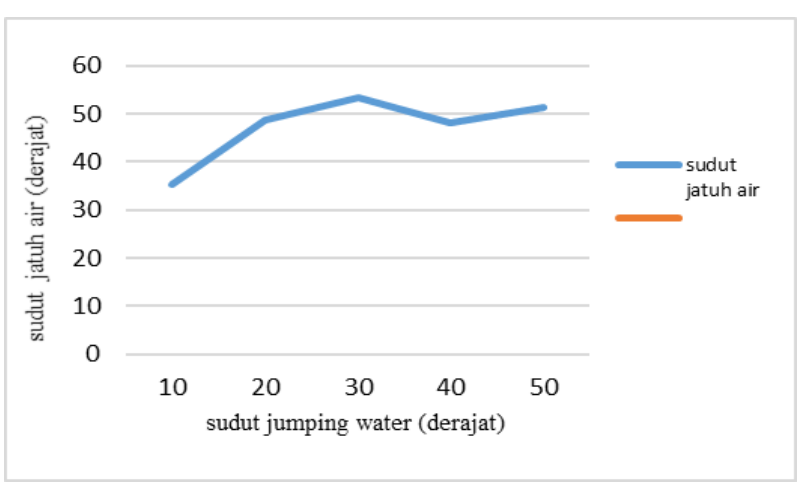

Fig. 7. Graph of angle falling water measurements

A. Measurement of spindle blade distance with jumping water

This measurement is carried out to determine the distance between the blade of the windmill and the Jumping water which will affect the turn of the mill, as shown in Figure (10). 


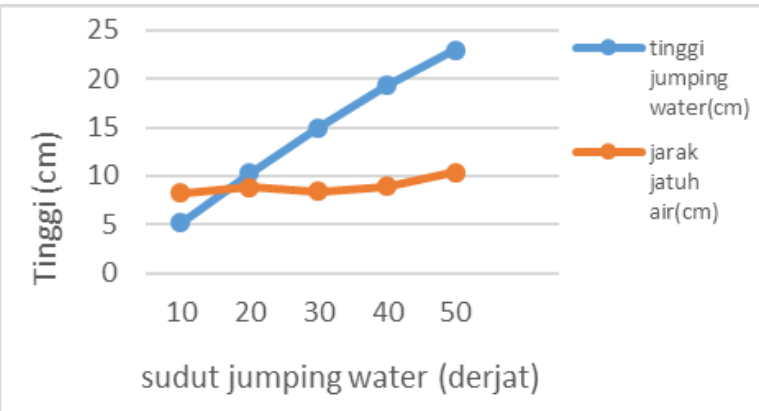

Fig. 8 High measurement graph of falling water and distance falling water against angle jumping water

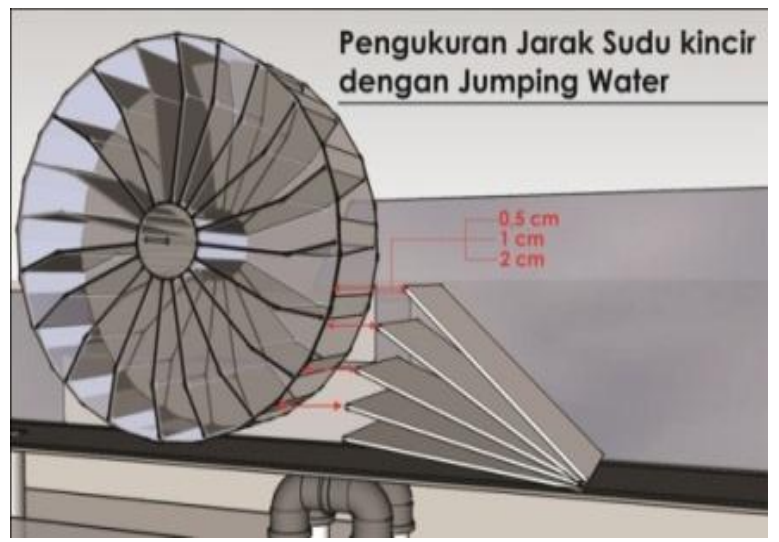

Fig. 9. Measuring the distance of the turbine blade with Jumping Water

From the above data retrieving result, the turn of the mill with the ratio of the distance between the blade of the windmill with Jumping water can be inferred or in the average according to the angle/height of jumping water, which is inputted into table (4)

TABLe 3 MEASUREMENTS Without JUMPING WATER

\begin{tabular}{|c|c|c|}
\hline angle JW & Spindle blade distance to JW & Rpm \\
\hline $\mathbf{0}^{\mathbf{o}}$ & - & 5 \\
\hline $\mathbf{0}^{\mathbf{0}}$ & - & 6,6 \\
\hline $\mathbf{0}^{\mathbf{0}}$ & - & 5,8 \\
\hline
\end{tabular}

TABLE 4 MEASUREMENTS WITH JUMPING WATER

\begin{tabular}{|c|c|c|}
\hline angle JW & Spindle blade distance to JW & Rpm \\
\hline $\mathbf{1 0}^{\mathbf{o}}$ & $0,5 \mathrm{~cm}$ & 7 \\
\hline $\mathbf{1 0}^{\mathbf{o}}$ & $1 \mathrm{~cm}$ & 6,8 \\
\hline $\mathbf{1 0}^{\mathbf{o}}$ & $2 \mathrm{~cm}$ & 5,8 \\
\hline
\end{tabular}

\begin{tabular}{|c|c|c|}
\hline angle JW & Spindle blade distance to JW & Rpm \\
\hline $\mathbf{2 0}^{\mathbf{0}}$ & $0,5 \mathrm{~cm}$ & 20,43 \\
\hline $\mathbf{2 0}^{\mathbf{o}}$ & $1 \mathrm{~cm}$ & 14 \\
\hline $\mathbf{2 0}^{\mathbf{0}}$ & $2 \mathrm{~cm}$ & 8 \\
\hline
\end{tabular}

\begin{tabular}{|c|c|c|}
\hline angle JW & Spindle blade distance to JW & Rpm \\
\hline $\mathbf{3 0}^{\mathbf{}}$ & $0,5 \mathrm{~cm}$ & 26,93 \\
\hline $\mathbf{3 0}^{\mathbf{0}}$ & $1 \mathrm{~cm}$ & 22,4 \\
\hline $\mathbf{3 0}^{\mathbf{0}}$ & $2 \mathrm{~cm}$ & 15,7 \\
\hline
\end{tabular}

\begin{tabular}{|c|c|c|}
\hline angle JW & Spindle blade distance to JW & Rpm \\
\hline $\mathbf{4 0}^{\mathbf{}}$ & $0,5 \mathrm{~cm}$ & 28,16 \\
\hline $\mathbf{4 0}^{\mathbf{o}}$ & $1 \mathrm{~cm}$ & 24,2 \\
\hline $\mathbf{4 0}^{\mathbf{0}}$ & $2 \mathrm{~cm}$ & 22,3 \\
\hline
\end{tabular}

\begin{tabular}{|c|c|c|}
\hline angle JW & Spindle blade distance to JW & Rpm \\
\hline $\mathbf{5 0}^{\mathbf{}}$ & $0,5 \mathrm{~cm}$ & 30,86 \\
\hline $\mathbf{5 0}^{\mathbf{o}}$ & $1 \mathrm{~cm}$ & 29,8 \\
\hline $\mathbf{5 0}^{\mathbf{0}}$ & $2 \mathrm{~cm}$ & 27,93 \\
\hline
\end{tabular}

From the average comparison of the distance between the spindle blades with Jumping Water above shows that the revolution of the mill turns can increase and also the power generated will be greater in accordance with the height of Jumping Water and also the distance between the wind blade and Jumping Water

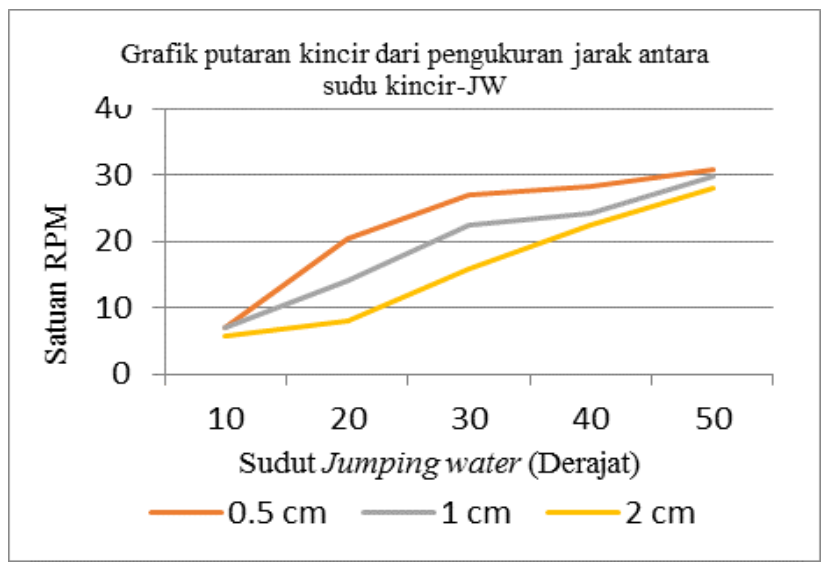

Figure.10. rotation of a millwheel from measuring the distance between a water wheel against a jumping water

\section{CONCLUSION}

Based on the result of making, assembling and application of jumping water at this PLTMH directly with this writer take the conclusion based on data collecting either by performance test, tool design and system work of jumping water at PLTMH. Here are the conclusions that can be taken:

1. The round by using jumping water from $10 \mathrm{o}-50 \mathrm{o}$ is very influential on the rotation of the mill, the higher the angle jumping water the faster the round produced by the wheel.

2. High jumping water effect on the distance and angle of falling water (experiments without a mill) the higher the angle then the distance falling water and the falling angle of water is also getting bigger

3. The distance between the water wheel against the jumping water is very influential on the waterwheel spin, the farther the distance then the waterwheel turns down.

\section{V.SUGGESTION}

Suggestions for further development is the use of jumping water on this micro-hydro prototype by adding automatic drive system in jumping water in order to raise and lower jumping water automatically in order to facilitate during the 
operation of this prototype in the laboratory. Acknowledgments to Kemenristek Dikti special DRPM for the grant aid of research given so this research can be done well.

\section{REFERENCES}

[1] BACH C. v., 1886, Die Wasserräder (The water wheels, in German), Konrad Wittwer Verlag,Stuttgart.

[2] Denny, M, 2004., The Eficiency of overshot and undershot waterwheels. European Journal of Phisics 25(2): 193-202

[3] Felix Mwema, Gheewala Shabbir H. 2012 Environmental assessment of electricity production in Tanzania. Energy for Sustainable Development December 2012

[4] Praful Yelguntwar, Pranay Bhange, Yogesh Lilhare, Ankit Bahadure, 2014, Design, Fabrication \& Testing of a Waterwhell for power generation in a $\mathrm{n}$ open channel flow, International Journal of Resach in
Engineering and Advanced Technology (IJERAT), volume 2 issue 1, feb-mar 2014

[5] Quaranta E, Ravelli R. 2015,. Out put power and power losses estimatiom for an overshot water wheel, journal renewable energy elsevior

[6] Quaranta E, Ravelli R. 2016., Optimization of Berastshot water wheels performance using different inflow configuration, journal renewable energy elsevior

[7] Rinaldi, 2015, Model Fisik Kincir air sebagai pembangkit listrik, annual civil Engineering seminar pekanbaru 2015. ISBN 978-979-792-636-6.

[8] Syafriyudin, 2016, "Peningkatan kapasitas Pembangkit Listrik Tenaga Mikrohidro di desa wisata Kebon Agung kecamatan Imogiri, Kabupaten Bantul Yogyakarta". Proseding Seminar Nasional Pendidikan Tinggi Vokasi Indonesia. Universitas Haluoleo. Kendari.8 Maret 2016. 